\title{
The effect of ultrasound on the treatment of domestic wastewater from organic and biological contamination
}

\author{
Uliana Vashkurak $^{\mathrm{a}}$, Liliya Shevchuk ${ }^{\mathrm{a}}$, Ivan Aftanaziv ${ }^{\mathrm{b}}$, Anna Romaniv ${ }^{\mathrm{c}}$ \\ ${ }^{a}$ Department of Technology of organic products, Lviv Polytechnic National University, Sq. St. \\ George. 2, Lviv, Ukraine \\ ${ }^{b}$ Department of Descriptive Geometry and Engineering Graphics, Lviv Polytechnic National \\ University, st. Metropolitan Andrew, 5, Lviv, Ukraine
}

${ }^{c}$ Chornovil Institute for Sustainable Development, Lviv Polytechnic National University, st. General Chuprinka, 130, Lviv, Ukraine

ulianavashkurak@gmail.com

Keywords: ultrasonic cavitation, domestic wastewater, microbial number, chemical oxygen demand. The effectiveness of the uses of ultrasonic cavitation for wastewater treatment has been investigated. The influence of the gases of different nature (nitrogen, oxygen, air, mixture of nitrogen and oxygen gases in the ratio of 1:1) on the destruction of organic and biological contaminants has been carried out. It is confirmed that ultrasound cavitation increases the purification effect of gases. It is established that the deepest purification from organic contaminants was achieved by the common action of air with ultrasound, the degree of water purification from organic compounds being $80 \%$ and from biological contaminants - by the common action of nitrogen with ultrasound - the degree of water purification from biological compounds being 99,5\%. The effective rate constant was calculated.

\section{Introduction}

Sewage water known also as domestic wastewater comes from households of villages, towns and cities as a result of daily water consumption. Main sources of sewage wastewater are toilets, kitchens, sinks, bathrooms etc. In addition to natural organic pollutants, detergent derivatives being the source of artifical pollutants are abundant in municipal wastewater. According to Eddy \& Metcalf Wastewater Engineering, $40 \%$ of sewage water comes from baths, 15\% from laundering, 10\% from kitchens and $5 \%$ from other sources.

Domestic wastewater causes no less environmental damage than industrial wastewater. Domestic wastewater includes both organic and biological contaminants of different nature. The problem of treatment of such type of wastewater is urgent not only for Ukraine but also for many other countries.

The use of hydrophytic structures, which are successfully used for the treatment of domestic 
wastewater in the Netherlands, Japan, China, Italy, the USA, Norway, Australia, France, etc. is widespread. According to experimental studies of the process of domestic wastewater treatment using water hyacinth in the United States, the degree of purification by BOD (biological oxygen demand) reaches 97-98\% [1]. Another technology used for water treatment is phytotechnology. Treatment plants based on phytotechnology can be used in different climatic conditions of Ukraine for wastewater treatment with costs from several tens to several thousand cubic meters per day [2]. For more than 30 years, phytotechnology has become widespread in Ukraine and in the world for the treatment of both domestic and agricultural and some types of industrial wastewater [3].

In Ireland, the system of common treatment of domestic wastewater (72\%) and surface runoff $(28 \%)$ is successfully operated, being constructed in the form of three shallow lagoons, two of which are planted with reeds and antlers, and the third is a floating water plant biofuel and duckweed. After purification in this system, water has the following parameters: BOC (biological oxygen consumption) - $9 \mathrm{mg} / \mathrm{dm}^{3}$, suspended solids - $9 \mathrm{mg} / \mathrm{dm}^{3}$, total nitrogen - 14.2 $\mathrm{mg} / \mathrm{dm}^{3}$, ammonia $-0.8 \mathrm{mg} / \mathrm{dm}^{3}$, nitrates -9.2 $\mathrm{mg} / \mathrm{dm}^{3}$, total phosphorus - $4.45 \mathrm{mg} / \mathrm{dm}^{3}$, orthophosphates - $3.15 \mathrm{mg} / \mathrm{dm}^{3}$. The average percentage reduction in the concentrations of pollutants in the system over the two-year study period was: BOC - 48\%, suspended matter -
$83 \%$, nitrogen - $51 \%$, phosphorus - $13 \%$, removal of pathogens - 99,77\% [4].

Bioplate structures are created mainly in areas where natural climatic conditions and environmental factors provide optimal conditions for the germination and vegetation of aquatic plants. The research of many scientists, in particular: P. D. Jenssen, T. Mahlum, T. Krogstad [5] is devoted to the work of many phytotechnology facilities under different conditions and features of the choice of design of treatment plants.

Biological methods are used for the purification of domestic and industrial wastewater from various dissolved organic and some inorganic (hydrogen sulfide, ammonia, etc.) compounds. A very simple and ancient way of biological wastewater treatment is to use a conventional septic tank. In septic tanks the use of biological products is provided. Bio-Industries Group (Ireland) is the most effective in the world today. The drug eliminates unpleasant odors and destroys pathogens.

Peru generates approximately $2217946 \mathrm{~m}^{3}$ of wastewater per day being discharged to the sewage system, only $32 \%$ of it receiving treatment. The rest of the water is discharged to the rivers which contain fecal coliform bacteria. Preliminary analysis of the domestic wastewater of the Carhuaz district was carried out, revealing total amount of coliform bacteria (at $35^{\circ} \mathrm{C}$ ) of $240,000 \mathrm{CFU} / 100 \mathrm{~mL}$ and thermotolerant coliform bacteria (at $44.5^{\circ} \mathrm{C}$ ) of 130,000 
CFU/100 $\mathrm{mL}$ exceeding the environmental standard values. The treatments were carried out with the air-ozone micro-nanobubbles generator, reducing total amount of coliform bacteria to 100 $\mathrm{CFU} / 100 \mathrm{~mL}(99.96 \%)$ and fecal coliform bacteria to $100 \mathrm{CFU} / 100 \mathrm{~mL}(99.92 \%)$ [6].

The investigations of the influence of ultrasonic waves on pollutants of different nature are conducted by scientists from different countries.

Cavitation was found to have a bactericidal effect. Increasing the duration of ultrasound (US) increases the degree of sewage treatment from fecal microorganisms up to $99.95 \%$. Secondary sewage treatment by ultrasound (US) reduces organic matter content by $30 \%$. So, complex methods of water purification have practical application, one of their stages being ultrasonic sewage treatment. [7].

The action of ultrasound on domestic wastewater containing organic contamination being investigated, it was determined that cavitation can decrease the value of COD by $25-30 \%$. In addition, it has been revealed that insoluble compounds turn into soluble ones [8].

Bisphenol A (BPA) which can be found not only in industrial wastewater but also in natural waters decomposes to $33.2 \%, 44.9 \%, 51.1 \%$ and $55.0 \%$ respectively with ultrasonic intensities of 20 $\mathrm{W} / \mathrm{cm}^{2}, 40 \mathrm{~W} / \mathrm{cm}^{2}, 60 \mathrm{~W} / \mathrm{cm}^{2}$ and $80 \mathrm{~W} / \mathrm{cm}^{2}$ [9]. As the micro-bubble treatment of household wastewater shows good results, it is advisable to study this process in more detail. In this work, the study of cavitation phenomena during the process of wastewater treatment from biological contamination was carried out.

\section{Experimental part}

The object of the study was wastewater from Lviv treatment plants. The experiments were carried out at a temperature of $20^{\circ} \mathrm{C}$, atmospheric pressure and a frequency of ultrasonic vibrations of $22 \mathrm{kHz}$.

The determination of chemical oxygen demand (COD) was performed by a dichromate method. The most common method for the determination of COD in both natural and waste water is the dichromate method, in which the oxidation of substances is carried out with a mixture of $\mathrm{K}_{2} \mathrm{Cr}_{2} \mathrm{O}_{7}+\mathrm{H}_{2} \mathrm{SO}_{4}$ at boiling.

COD was calculated by the equation:

$C O D=\frac{(1000 *(V 1-V 2) * K * T)}{\text { Vsample }}, \mathrm{mgO}_{2} / \mathrm{dm}^{3}(1)$

where: V1 is the volume of the solution of the Mohr's salt spent on the single experience, $\mathrm{cm}^{3}$; V2 is the volume of the Mohr's salt spent on the titration of the sample, $\mathrm{cm}^{3}$;

Vsample is the volume of the sample of water taken for the analysis, $\mathrm{cm}^{3}$;

$\mathrm{T}=1.6 \mathrm{mg}$ is the mass of oxygen equivalent to 1 $\mathrm{cm}^{3}$ of $0.2 \mathrm{n} \mathrm{K}_{2} \mathrm{Cr}_{2} \mathrm{O}_{7}$ solution;

$\mathrm{K}$ is the correction factor for the $\left(\mathrm{NH}_{4}\right)_{2} \mathrm{Fe}\left(\mathrm{SO}_{4}\right)_{2} \cdot 6 \mathrm{H}_{2} \mathrm{O}$ concentration.

The sanitary - epidemiological assessment of water quality is conducted with the use of the microbial number $(\mathrm{MN})$ - the total number of bacteria in $1 \mathrm{~cm}^{3}$. The essence of the method is to determine the total number of microorganisms 
capable of growing on a meat-peptone agar at a temperature of $37^{\circ} \mathrm{C} \pm 0.5^{\circ} \mathrm{C}$ for $24 \pm 2 \mathrm{~h}$ in $1 \mathrm{ml}$ of water, followed by the account of the colonies grown on the medium.

In this experiment we used acoustic cavitation occurring in the frequency range of $5-50 \mathrm{kHz}$. In acoustic cavitation, magnetostrictive emitters operate in resonant mode.

Research was carried out in the reactor made of stainless steel of grade H18N9T. US oscillations of frequency of $22 \mathrm{kHz}$ from a low-frequency generator USDN-2 (Ukraine) (power of $90 \mathrm{~W}$ ) were passed with the help of magnetostrictive emitter and immersed in the volume of the studied water $(150 \mathrm{ml})$. The fittings for sampling, supply and exit of gases were mounted in the reactor. The initial values of chemical consumption of oxygen and of microbial number were previously established.

\section{Results and discussion}

The initial value of COD was in the range 201.6 - $384 \mathrm{mgO}_{2} / \mathrm{dm}^{3}$. Since the initial value of COD ranges widely, it is advisable to use the ratio of $\mathrm{COD} / \mathrm{COD}_{0}$. The output values of the $\mathrm{MN}$ fluctuate in the range $410-2520 \mathrm{CFU} / \mathrm{cm}^{3}$, therefore, it is advisable to use the ratio $\mathrm{MN} / \mathrm{MN}_{0}$.

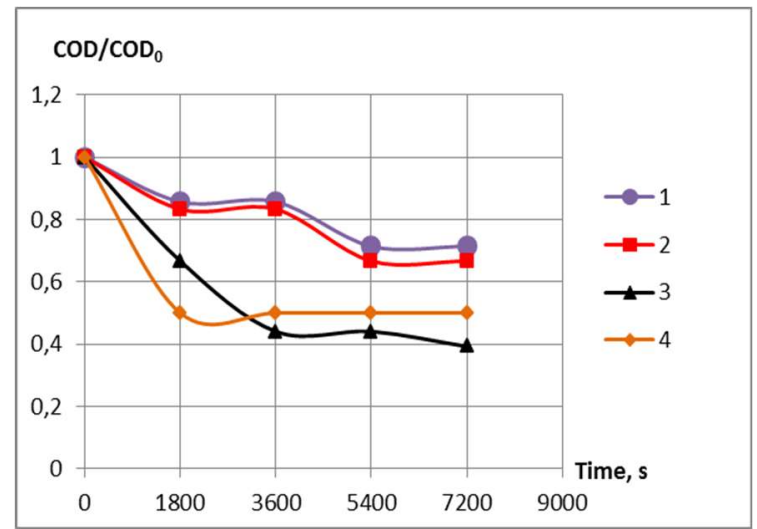

Figure. 1. Character of dependence of ratio $\mathrm{COD} / \mathrm{COD}_{0}$ on duration of cleaning domestic wastewater under different experimental conditions: $1-\mathrm{N}_{2} ; 2-\mathrm{O}_{2} ; 3-\mathrm{N}_{2}+\mathrm{O}_{2} ; 4$-Air

Mixture of nitrogen and oxygen has the ratio of 1 , meaning the mixture of pure nitrogen and oxygen in equal quantities, whereas air, besides nitrogen and oxygen, also contains other gases.

The analysis of obtained results of the study included the effect of all investigated gases (nitrogen, oxygen, air, mixture of nitrogen and oxygen in the ratio of 1 . Figure 1 shows that during the first hour of the experiment the results close to the bubbling of nitrogen and oxygen, namely, a decrease in an average of 1.18 times from the initial value, were observed. Air bubbling and the mixture of nitrogen and oxygen in the ratio 1:1 showed a deeper purification and decrease on average 2.1 times from the initial value during the first hour of the process. A similar trend was observed up to $120 \mathrm{~min}$ of conducting the experiment. In the end, the reduction of the COD was 1.4 and 1.5 times the initial value with the bubbling of nitrogen and oxygen, respectively; air bubbling and bubbling a mixture of nitrogen and oxygen in the ratio of 
1:1 reduced the value of COD by 2 and 2.5 times from the initial value, respectively.

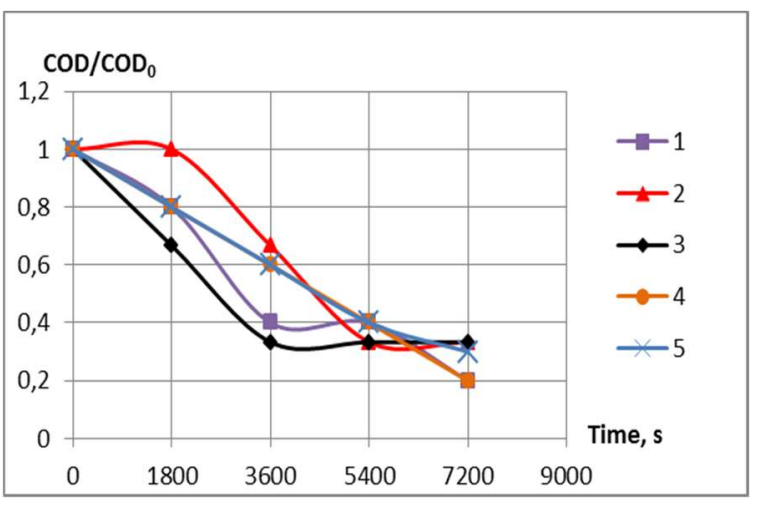

Figure. 2. Character of sound and chemical dependence of ratio $\mathrm{COD} / \mathrm{COD}_{0}$ on duration of cleaning domestic wastewater under different experimental conditions: 1$\mathrm{N}_{2} / \mathrm{US} ; 2-\mathrm{O}_{2} / \mathrm{US} ; 3-\left(\mathrm{N}_{2}+\mathrm{O}_{2}\right) / \mathrm{US}$; 4-Air/US; 5-US

While studying the effect of the combined action of US with gases of different nature (nitrogen, oxygen, air, a mixture of nitrogen and oxygen in the ratio of 1:1), it was observed that in $30 \mathrm{~min}$ of conducting the experiment the common action of the US with oxygen had no significant effect (see Figure 2). With the combined action of air from the US, nitrogen from the US and the action of the US itself, a similar result was observed only 1.25 times less than the initial value. With a combined action of a mixture of nitrogen and oxygen in the ratio of 1:1 with US, the deepest purification was observed - a decrease by 1.5 times from the initial value. In 90 minutes of the process, the obtained results under all the studied process conditions are close, the average degree of water purification from organic compounds is $62.6 \%$. However, in 120 minutes, sewage treatment with the combined action of nitrogen with US and air with US is more effective (the degree of water purification from organic pollution is $78 \%$ and $80 \%$ in accordance), than with the combined action of oxygen with US, a mixture of nitrogen and oxygen in the ratio of $1: 1$ (the degree of water purification from organic pollution is $66,6 \%$ for both cases) and US itself, the degree of water purification from organic pollution is $70 \%$.

Analytical determining the effective constants of the rates of destruction of organic compounds and biological contaminants was carried out using the integral method from the relevant equations:

$\ln \frac{\mathrm{COD}}{\mathrm{COD} 0}=-\mathrm{k \tau}(2)$

$\ln \frac{\mathrm{MN}}{\mathrm{MN}_{0}}=-\mathrm{k \tau}(3)$

where $k$ is the effective constant of rate, $\mathrm{s}^{-1} ; \tau$ is the time of destruction of organic substances or $\mathrm{MN}$ in wastewater, $\mathrm{s}$.

The results in Table 1 confirm the results described above.

Table 1. Comparative characteristic of effective constant of the rates of organic contaminants of the domestic wastewater

\begin{tabular}{|l|r|l|l|l|}
\hline $\begin{array}{l}\text { Condition } \\
\text { of the } \\
\text { process }\end{array}$ & $\begin{array}{l}\text { WS, } \\
\mathrm{k}^{*} 10^{4}, \\
\mathrm{~s}^{-1}\end{array}$ & $\mathrm{R}^{2}$ & $\begin{array}{l}\text { Without } \\
\mathrm{US},\end{array}$ & $\mathrm{R}^{2}$ \\
\hline $\mathrm{N}_{2}$ & 0.5 & 0.89 & 2.1 & 0.92 \\
\hline $\mathrm{O}_{2}$ & 0.6 & 0.89 & 1.6 & 0.9 \\
\hline $\mathrm{N}_{2}+\mathrm{O}_{2}$ & 1.5 & 0.81 & 1.6 & 0.78 \\
\hline Air & 1.3 & 0.78 & 2.2 & 0.99 \\
\hline US & - & - & 1.9 & 0.98 \\
\hline
\end{tabular}

Different gases dissolve in water differently. The rate of gas diffusion into the cavity and, therefore, the gas content in it, is significantly affected by the solubility of the gas. There is a 
direct proportional relationship between the molecular weight of the gas and its solubility in water.

Electric charges occur in cavitation cavities during sonication, due to which water molecules are exposed to strong ionization

$\mathrm{H}_{2} \mathrm{O} \rightarrow \mathrm{H}^{\bullet}+{ }^{\cdot} \mathrm{OH}$,

$\mathrm{H}^{\cdot}+\mathrm{O}_{2} \rightarrow \mathrm{HO}_{2}{ }^{\bullet}$.

At simultaneous presence of both organic substances and bacterial contamination in the medium and passing a certain gas through this water in the presence of US oscillations, simultaneous influence of cavitation on contaminated water, intensified by the nature of certain gas occurs.

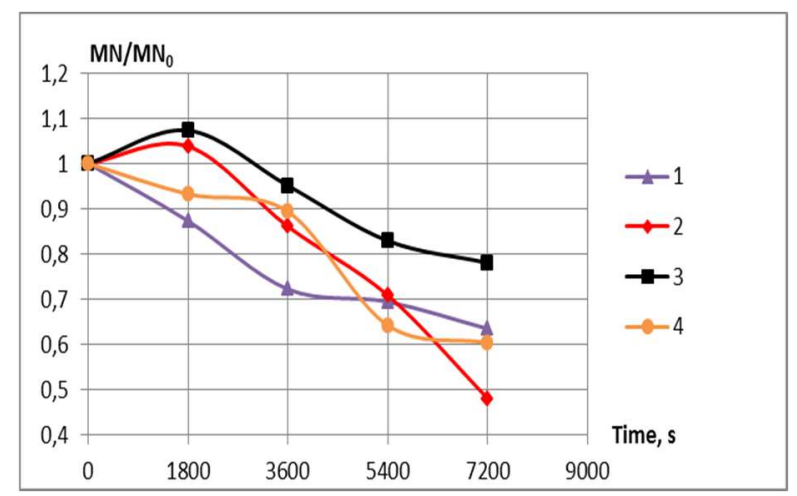

Figure. 3: Character of dependence of ratio $\mathrm{MN} / \mathrm{MN}_{0}$ on duration of cleaning domestic wastewater in presence of gases of various nature: $1-\mathrm{N}_{2} ; 2-\mathrm{O}_{2} ; 3-\mathrm{N}_{2}+\mathrm{O}_{2} ; 4$-Air

Figure 3 shows the results of the influence of gases of different nature (nitrogen, oxygen, air, mixture of nitrogen and oxygen in the ratio of 1:1) on the destruction of biological contaminants in the wastewater of the Lviv treatment plants. During the experiment (120 minutes), the least effective method proved to be bubbling of a mixture of nitrogen and oxygen gases in the ratio of $1: 1$ in the reaction medium, the final degree of water disinfection being $21.9 \%$. The impact of the remaining gases, namely nitrogen, oxygen and air, is not so clear, so it should be investigated in more detail. At the 60th minute of conducting the experiment the least effective is a mixture of nitrogen and oxygen gases in the ratio of $1: 1$, a decrease by 1.1 times from the initial value; the most effective is nitrogen, a decrease by 1.3 times the initial value; the effect of oxygen is mediocre, 1.16 times decrease from initial value. However, in 90 minutes, some other results of the process can be seen. The greatest amount of biological pollution is destroyed by the action of air, a decrease is 1.5 times from its initial value. The results obtained under the influence of nitrogen and oxygen are almost identical, a decrease by 1.4 times from the initial value. In 120 minutes of the process, the least purifying effect is shown by nitrogen, the degree of water disinfection being $36.5 \%$ (reduction from $2520 \mathrm{CFU} / \mathrm{cm}^{3}$ to 1600 $\mathrm{CFU} / \mathrm{cm}^{3}$ ). A slightly better result was obtained with air bubbling, the rate of water disinfection being $39.6 \%$ (decrease from $414 \mathrm{CFU} / \mathrm{cm}^{3}$ to 250 $\mathrm{CFU} / \mathrm{cm}^{3}$ ). The deepest purification was achieved by the action of oxygen, the degree of water disinfection being 51,9\% (decrease from $790 \mathrm{CFU} / \mathrm{cm}^{3}$ to $380 \mathrm{CFU} / \mathrm{cm}^{3}$ ).

As the tested bacteria are aerobes, there is an increase in $\mathrm{MN}$ in the presence of oxygen and air. Further combined action of the US and the atmosphere of these gases contributes to their destruction. 


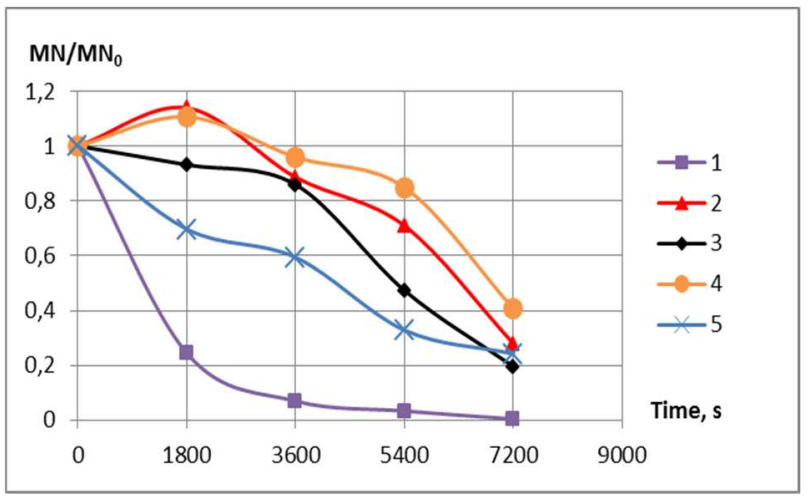

Figure. 4. Character of sound and chemical dependence of ratio $\mathrm{MN} / \mathrm{MN}_{0}$ on duration of cleaning domestic wastewater under different experimental conditions: 1$\mathrm{N}_{2} / \mathrm{US} ; 2-\mathrm{O}_{2} / \mathrm{US} ; 3-\left(\mathrm{N}_{2}+\mathrm{O}_{2}\right) / \mathrm{US} ; 4$-Air/US; 5-US;

Figure 4 shows the results with common action of US and investigated gases. It was established that during the first hour of the experiment identical values are observed for the common action of US with oxygen and with the mixture of nitrogen and oxygen in the ratio of 1:1 in the cavitation medium, showing a decrease of approximately 1.1 times the initial value. At the 90th minute of the process, the obtained results are no so similar, with oxygen bubbling reducing 1.4 times the initial value, bubbling the mixture of nitrogen and oxygen in the ratio of $1: 1$ reducing the amount of biological contaminants by 2.1 times from the initial value. When the air is fed into the cavitation medium, the result is lower, a decrease by 1.17 times the initial value. In 120 minutes of conducting the experiment, the lowest cleaning effect was when the air was combined with the US, the degree of water disinfection being 59.4\% (decrease from 542 $\mathrm{CFU} / \mathrm{cm}^{3}$ to $220 \mathrm{CFU} / \mathrm{cm}^{3}$ ). After the combined action of oxygen with US and the mixture of nitrogen and oxygen in the ratio of $1: 1$ with US mediocre results were obtained, the degree of water disinfection was $72,1 \%$ (decrease from 790 $\mathrm{CFU} / \mathrm{cm}^{3}$ to $380 \mathrm{CFU} / \mathrm{cm}^{3}$ ) and $80,4 \%$ (decrease from $440 \mathrm{CFU} / \mathrm{cm}^{3}$ to $\left.86 \mathrm{CFU} / \mathrm{cm}^{3}\right)$, respectively. At the action of the ultrasound itself, the degree of water disinfection was $75.7 \%$ (decrease from $1280 \mathrm{CFU} / \mathrm{cm}^{3}$ to $310 \mathrm{CFU} / \mathrm{cm}^{3}$ ), which is an average result. With the combined action of nitrogen with US, the decrease in amount of biological contamination during the whole process of the experiment was observed. However, the most visible effect was observed within $30 \mathrm{~min}$ of the experiment, namely, a decrease by 4.1 times from the initial value. Over the next 1.5 hours of the experiment, the cleansing effect was improved, but not so sharply. In 120 minutes, $99.5 \%$ water disinfection rate was obtained which is the best result (reduction from $1376 \mathrm{CFU} / \mathrm{cm}^{3}$ to 310 $\left.\mathrm{CFU} / \mathrm{cm}^{3}\right)$.

The data in Table 2 confirm the results described above.

Table 2. Comparative characteristic of effective constant of the rates of biologacal contaminants of the domestic wastewater

\begin{tabular}{|l|l|l|l|l|}
\hline $\begin{array}{l}\text { Conditional } \\
\text { of the } \\
\text { process }\end{array}$ & $\begin{array}{l}\text { Without } \\
\mathrm{US}, \\
\mathrm{k}^{*} 10^{4}, \\
\mathrm{~s}^{-1}\end{array}$ & $\mathrm{R}^{2}$ & $\begin{array}{l}\text { With } \\
\mathrm{US}, \\
\mathrm{k}^{*} 10^{4}, \\
\mathrm{~s}^{-1}\end{array}$ & $\mathrm{R}^{2}$ \\
\hline $\mathrm{N}_{2}$ & 0.7 & 0.93 & 7.2 & 0.79 \\
\hline $\mathrm{O}_{2}$ & 0.8 & 0.89 & 1.2 & 0.85 \\
\hline $\mathrm{N}_{2}+\mathrm{O}_{2}$ & 0.3 & 0.8 & 1.7 & 0.9 \\
\hline Air & 0.7 & 0.91 & 0.8 & 0.79 \\
\hline US & - & - & 1.6 & 0.96 \\
\hline
\end{tabular}


The high correlation coefficients added in Tables $1-2$ confirm the adequacy of the adopted model. The error in the determination of the rate constants in the wastewater estimated in three parallel experiments did not exceed $8 \%$.

\section{Conclusions}

The bubbling of the gases of different nature (nitrogen, oxygen, air, mixture of nitrogen and oxygen gases in the ratio of $1: 1$ ) has a positive effect on the treatment of domestic wastewater. In both cases, for destroying organic and biological contaminants, the best results were achieved with the combined action of nitrogen with US. Considering the obtained results, US cavitation could be used as a one of the steps of water purification domestic wastewater.

\section{References}

[1] KickuthR. WurzelraumverfahreninderPraxis. LandschaftundStadt. 1984 (16 ): 145-153.

[2] Zavacz'kyj S.V., Kotelchuk L.S., Kotelchuk A.L. Bioinzhenerni sporudy dlya ochy`shhennya stichnyx vod maloyi produktyvnosti. Chernigivskyj naukovyj chasopys (seriya 2). Texnika i pryroda. 2012. № 1(3): $57-63$

[3] Zavacz kyj S.V., Kotelchuk L.S., Kotelchuk A.L. Bioinzhenerni sporudy dlya ochyshhennya stichnyx vod maloyi produktyvnosti. Chernigivskyj naukovyj chasopys (seriya 2). Texnika i pryroda. 2012. № 1(3): 65-67

[4] Budonyj O. P., Avramishyna K. V. Bioplato yak perspektyvnyj sposib ochyshhennya stichnyx vod. www. essuir.sumdu.edu.ua.

[5] Jenssen, D., Mahlum, T., Krogstad, T. Potential Use of Constructed Wetlands for Wastewater Treatment in Northern Environments, Water Science \& Technology,1993, 28(10):149-157.
[6] Valverde J. Reduction of Coliforms presents in domestic residual waters by Air-Ozone MicroNanobubbles In Carhuaz city. FloresJournal of Nanotechnology.

[7] Mahvi AH. Application of Ultrasonic Technology for Water and Wastewater Treatment. School of Public Health and Center for Environmental Research, Tehran University of Medical Sciences, Iran17 Jun 2009

[8] Nasseri, S., Vaezi, F., Mahvi, A., Nabizadeh, R., \& Haddadi, S. (2006). Determination of the ultrasonic effectiveness in advanced waste water. Iran. Journal of Environmental Health Science and Engineering, 3(2), 109-116.

[9] Guo, Z., \& Feng, R. (2009). Ultrasonic irradiationinduced degradation of low-concentration bisphenol $A$ in aqueous solution. Journal of Hazardous Materials. 163(2-3), 855-860). 